\title{
Six-year single-centre experience in minimally invasive mitral valve repair - impact of the team learning curve on in-hospital clinical outcome
}

\author{
Witold Gerber ${ }^{1,2,3}$, Krzysztof Sanetra ${ }^{1,2}$, Małgorzata Kuczera ${ }^{2,4}$, Krzysztof Białek ${ }^{1,2}$, Marian Zembala ${ }^{3}$, \\ Marek Cisowski ${ }^{1,2}$ \\ ${ }^{1} 1^{\text {st }}$ Department of Cardiac Surgery, American Heart of Poland, Bielsko-Biala, Poland \\ ${ }^{2}$ Center for Cardiovascular Research and Development, American Heart of Poland, Bielsko-Biala, Poland \\ ${ }^{3}$ Department of Cardiac, Vascular and Endovascular Surgery and Transplantology in Zabrze, Medical University of Silesia \\ in Katowice, Poland \\ ${ }^{4}$ Department of Anesthesia and Intensive Care, American Heart of Poland, Bielsko-Biala, Poland
}

Kardiochirurgia i Torakochirurgia Polska 2019; 16 (1): 27-31

\begin{abstract}
Introduction: Minimally invasive mitral repair is less traumatic and more acceptable for the patient than traditional surgery. However, it is a challenging procedure that requires effort from all the personnel involved.

Aim: To investigate the results of the minimally invasive mitral valve repair learning curve at the institution.

Material and methods: The indication for the surgery was severe mitral regurgitation. Patients with other valvular insufficiency, body mass index (BMI) $>30 \mathrm{~kg} / \mathrm{m}^{2}$, ejection fraction (EF) $<45 \%$, aortic dilatation, reoperation, pleural adhesions, coronary artery disease requiring invasive treatment, and pregnant women were disqualified. The patients were assigned to one of three groups regarding their surgery date - group 1 (20122013), group 2 (2014-2015) and group 3 (2016-2017). The primary endpoints were death, myocardial infarction, stroke, an reoperation for mitral dysfunction. The investigation was performed to determine preoperative parameters (EuroSCORE, age, sex, BMI, arrhythmias, EF), intraoperative parameters (procedure, cross-clamp, extracorporeal circulation), and postoperative parameters (chest revision, transfusion, drainage, ventilation time, pleurocentesis, hospitalization time).

Results: There were 173 patients in total. One patient from group 1 ( $0.6 \%$ overall) died. No myocardial infarction or stroke was observed in any of the three groups. Chest revision count ( 5 vs. 1 vs. $1 ; p=0.0004$ ), total drainage (797.20 vs. 517.92 vs. $449.69 ; p=0.0018)$ and hospitalization time (7.89 vs. 7.18 vs. $6.73 ; p=0.0005$ ) were significantly different among the groups. The ventilation time, transfusion number and pleurocentesis count did not differ significantly.

Conclusions: The procedure is safe and ensures optimal perioperative results. The number of complications is low and acceptable.
\end{abstract}

Key words: learning curve, mitral valve, repair.

\section{Streszczenie}

Wprowadzenie: Małoinwazyjna naprawa zastawki mitralnej z dostępu przez minitorakotomię jest w porównaniu z klasyczną chirurgią mniej traumatyczną i bardziej akceptowalną przez pacjenta formą leczenia. Procedura i prowadzenie pacjenta w okresie okołooperacyjnym są jednak trudne i wymagają zaangażowania całego personelu medycznego.

Cel: Analiza krzywej uczenia i wyników operacji małoinwazyjnej naprawy zastawki mitralnej na oddziale.

Materiat i metody: Wskazaniem do przeprowadzenia procedury była izolowana, ciężka niedomykalność zastawki mitralnej. Pacjenci z innymi wadami zastawkowymi, wskaźnikiem masy ciała $(\mathrm{BMI})>30 \mathrm{~kg} / \mathrm{m}^{2}$, frakcją wyrzutową < 45\%, poszerzeniem aorty wstępującej, poddawani ponownej operacji, ze zrostami opłucnowymi, chorobą niedokrwienną serca wymagającą leczenia interwencyjnego oraz kobiety w ciąży nie byli kwalifikowani do zabiegu. Chorych podzielono na podstawie czasu przeprowadzenia zabiegu na trzy grupy: grupa 1. (2012-2013), grupa 2. (2014-2015) oraz grupa 3. (2016-2017) Do pierwszorzędowych punktów końcowych zaliczono: zgon, zawał serca, udar, ponowną operację z powodu dysfunkcji zastawki mitralnej. Ponadto przeprowadzono szczegółową analizę w kierunku oceny danych przedzabiegowych (EuroSCORE, wiek, płeć, BMI, arytmie, frakcja wyrzutowa), śródzabiegowych (czas zakleszczenia aorty, czas krążenia pozaustrojowego) oraz pozabiegowych (rewizje klatki piersiowej, transfuzja, drenaż, czas wentylacji, nakłucia opłucnej, czas hospitalizacji).

Wyniki: Analizie poddano 173 pacjentów. Jeden pacjent z grupy 1. (0,6\% wszystkich chorych) zmart w okresie pozabiegowym. Nie stwierdzono udaru mózgu ani zawału serca w żadnej z grup. Liczba rewizji klatki piersiowej (5 vs 1 vs 1; $p=0,0004)$, drenaż całkowity $(797,20$ vs 517,92 vs 449,$69 ; p=0,0018)$ oraz czas hospitalizacji $(7,89$ vs 7,18 vs 6,$73 ; p=0,0005)$ różniły się istotnie pomiędzy grupami. Różnice w liczbie transfuzji, nakłuć

Address for correspondence: Krzysztof Sanetra MD, $1^{\text {st }}$ Department of Cardiac Surgery, American Heart of Poland, 101 Armii Karajowej St, 43-316 Bielsko-Biala, Poland, phone: +48 692030 003, e-mail: krzyssan@poczta.onet.pl

Received: 18.12.2018, accepted: 8.02.2019. 
opłucnej oraz czasie wentylacji mechanicznej nie były istotne statystycznie.

Wnioski: Procedura małoinwazyjnej naprawy zastawki mitralnej jest bezpieczna i zapewnia optymalne wyniki okołozabiegowe. Liczba powikłań jest niska i akceptowalna.

Słowa kluczowe: krzywa uczenia, zastawka mitralna, naprawa.

\section{Introduction}

The aspect of the learning curve for innovative procedures has been widely analyzed in many centers across the globe. The minimally invasive mitral valve repair program was deeply inspected in Leipzig, where 17 surgeons learned and performed 3895 procedures through right mini-thoracotomy (data from 2013) [1]. The report provided high quality data referring to both personal and institutional education. Minimally invasive mitral valve repair is less traumatic and more acceptable for a patient. However, it is a challenging procedure that requires a huge amount of effort from all the personnel involved. We believe that every minimally invasive program requires constant evaluation and improvement. Consequently, we created a prospective registry to record all clinical data from minimally invasive mitral valve repair at our institution.

\section{Aim \\ The aim of the study was to investigate the results of the minimally invasive mitral valve repair learning curve at the institution.}

\section{Material and methods \\ Patients}

The qualification criteria for isolated mitral valve repair through mini-thoracotomy were: severe mitral regurgitation in accordance with European Society of Cardiology/ European Association for Cardiothoracic Surgery guidelines (flail leaflet/ruptured papillary muscle/large coaptation defect; very large central jet or eccentric jet adhering, swirling, and reaching the posterior wall of the left atrium; dense/ triangular continuous wave signal of regurgitant jet; large flow convergence zone; $\geq 7$ vena contracta width; systolic pulmonary vein flow reversal; E-wave dominant $\geq 1.5 \mathrm{~m} / \mathrm{s}$; time velocity integral (TVI) mitral/TVI aortic > 1.4; effective regurgitant orifice area $\left(\mathrm{mm}^{2}\right) \geq 40$; regurgitation volume (ml/beat) $\geq 60$; enlargement of left atrium/left ventricle), and age $>18$. Patients with other valvular insufficiency requiring intervention, body mass index $(\mathrm{BMI})>30 \mathrm{~kg} / \mathrm{m}^{2}$, ejection fraction $(E F)<45 \%$, aortic dilatation, pleural adhesions, coronary artery disease requiring invasive treatment, pregnant women and reoperated patients were disqualified from this kind of procedure.

The patients were qualified for the surgery on the basis of their echocardiography and clinical status. In patients $>40$ years old, supplementary coronarography was performed before the admission to the cardiac surgery depart- ment. The surgical risk was calculated with the EuroSCORE risk scale. The patient was qualified for the procedure if he/ she fulfilled the qualification criteria, regardless of calculated surgical risk.

\section{The procedure}

On the day of admission to the hospital, the patients underwent all the necessary laboratory tests (electrolytes, morphology, coagulation, creatinine, troponin) and physical examination and gave their consent for the procedure. The control echocardiography and ECG were performed.

All the procedures were performed by a single surgeon. Combined, general anesthesia was induced in all patients. Invasive arterial blood pressure monitoring (preferably radial artery) was performed. Each patient was intubated and the central venous port was introduced (preferably right jugular vein). The echo probe for transesophageal monitoring was introduced. The Foley catheter was passed into the bladder.

The heparin was given in a dose calculated on the basis of the patient's body mass. When the activated clotting time reached 480 seconds, the cannulation for cardiopulmonary bypass was acquired through femoral vessels using the Seldinger technique. The incision for mitral valve access was made in the fourth intercostal space. The crystalloid cardioplegia was given antegradely into the aorta after cross-clamping the vessel distally with a Chitwood clamp. The atriotomy, final valve assessment and repair were performed.

Each annuloplasty ring was implanted using single sutures. All additional repair procedures were conducted in a standard technique. The carbon dioxide was inflated into the operating field until the atriotomy was closed. The atriotomy closure was made with a continuous suture. After removal of the aortic cross-clamp, transesophageal echocardiography was used to evaluate proper valvular function. The heparinization was fully reversed with protamine sulfate after weaning from cardiopulmonary bypass and removal of the cannulas. Two epicardial electrodes were implanted and the chest tube was introduced into the right pleura. Patients who received a bioprosthesis or mechanical valve were excluded from the study, as perioperative and postoperative protocols slightly differ.

After the procedure, every patient was transferred to the early postoperative intensive care unit. Constant monitoring of ECG, blood pressure, blood saturation, drainage and diuresis was sustained. Blood gasometry was obtained every hour. The laboratory test panel and chest radiogram were acquired. 
The chest tube was removed 24 hours after the surgery. The monitoring equipment was removed and the patient was transferred to the ward. On the day of discharge, final ECG, laboratory test panel and transthoracic echocardiography were performed.

The pharmacotherapy was adjusted individually. Additionally, each patient received a vitamin $K$ antagonist (acenocoumarol or warfarin). The target international normalized ratio (INR) was 2.5-3.5. Low-weight molecular heparin was administered until the INR was $>2$.

\section{Outcomes}

The early perioperative results from the consecutive patients from the years 2012-2017 were analyzed. The patients were arbitrarily divided into three groups:

a) group 1: patients operated on in 2012-2013,

b) group 2: patients operated on in 2014-2015,

c) group 3: patients operated on in 2016-2017.

The primary endpoints were death, myocardial infarction, stroke, and reoperation for mitral dysfunction. The investigation was also performed to determine preoperative parameters (EuroSCORE, age, sex, BMI, arrhythmias, EF), intraoperative parameters (procedure, cross-clamp, extracorporeal circulation), and postoperative parameters (chest revision, transfusion, drainage, ventilation time, pleurocentesis, hospitalization time).

\section{Statistical analysis}

The data are shown as mean \pm standard deviation or number (percentage). The Shapiro-Wilk test rejected normal distribution in the most analyzed parameters. Therefore, the Kruskal-Wallis test was used for continuous data analysis, followed by the Dunn test for multiple comparisons. The $\chi^{2}$ test was used for categorical data analysis. The data were analyzed using MedCalc v.18.5 (MedCalc Software, Belgium). The $p$-value less than 0.05 was considered statistically significant.

\section{Results}

A group of 173 consecutive patients operated on in the years 2012-2017 was arbitrarily divided into 3 subgroups:
Table I. Preoperative parameters

\begin{tabular}{lcccc}
$\begin{array}{l}\text { Preoperative } \\
\text { parameter }\end{array}$ & $\begin{array}{c}\text { Group 1 } \\
(2012-2013) \\
(n=29)\end{array}$ & $\begin{array}{c}\text { Group 2 } \\
(2014-2015) \\
(n=62)\end{array}$ & $\begin{array}{c}\text { Group 3 } \\
(2016-2017) \\
(n=82)\end{array}$ & P-value \\
\hline EF (\%) & $61.25 \pm 10.66$ & $69.10 \pm 8.03$ & $68.57 \pm 7.54$ & 0.002 \\
\hline Age [years] & $51.04 \pm 12.99$ & $47.23 \pm 14.95$ & $51.43 \pm 14.12$ & 0.21 \\
\hline Male, $n(\%)$ & $23(79)$ & $41(66)$ & $59(72)$ & 0.42 \\
\hline BMI [kg/m²] & $25.8 \pm 6.5$ & $25.2 \pm 5.4$ & $27.8 \pm 4.1$ & 0.97 \\
\hline AF, $n(\%)$ & $9(31)$ & $11(17.7)$ & $14(17)$ & 0.32 \\
\hline Add. EuroSCORE & $3.26 \pm 1.99$ & $2.98 \pm 2.04$ & $3.17 \pm 1.70$ & 0.49 \\
\hline EuroSCORE II (\%) & $0.66 \pm 0.22$ & $0.67 \pm 0.21$ & $0.70 \pm 0.23$ & 0.55 \\
\hline $\begin{array}{l}\text { Severe MI (ESC2012 } \\
\text { Guidelines), } n(\%)\end{array}$ & $29(100)$ & $62(100)$ & $82(100)$ & 1 \\
\hline Data & & & & \\
\hline
\end{tabular}

Data are shown as mean \pm standard deviation or number (percentage).

$\mathrm{AF}$ - atrial fibrillation, $\mathrm{BMI}$ - body mass index, $\mathrm{EF}$ - ejection fraction, $\mathrm{MI}$ - mitral insufficiency.

a) group 1: patients operated on in 2012-2013 - 29 patients. b) group 2: patients operated on in 2014-2015 - 62 patients, c) group 3: patients operated on in 2016-2017- 82 patients. The investigation to determine preoperative parameters is summarized in Table I.

The groups did not differ in terms of calculated perioperative risk, age, sex, or body mass index. All but 1 patient from group 1 underwent successful minimally invasive mitral valve repair. The procedures were various (Table II). Both cross-clamp time and extracorporeal circulation time declined in successive time intervals (Figs. 1, 2).

One patient had early reoperation for mitral dysfunction in 2012. The same patient died due to postoperative complications $(0.6 \%$ overall mortality). No myocardial infarction or stroke was observed in any of the three groups. Chest revision count and total drainage and hospitalization time were significantly different among the groups, favoring each successive time interval (Table III, Fig. 3). The mechanical ventilation time, number of transfusions and pleurocentesis count did not differ significantly (Table III).

No major vascular complications associated with the use of the Seldinger method were noted. A few patients suffered from lymphatic leakage, which required groin revision in 3 cases.

Table II. Procedures $(n=173)$

\begin{tabular}{|c|c|c|c|c|}
\hline Procedure & $\begin{array}{l}\text { Group } 1 \text { (2012-2013) } \\
\quad(n=29)\end{array}$ & $\begin{array}{c}\text { Group } 2 \text { (2014-2015) } \\
\quad(n=62)\end{array}$ & $\begin{array}{c}\text { Group } 3 \text { (2016-2017) } \\
(n=82)\end{array}$ & $P$-value \\
\hline Annuloplasty ring implantation, $n(\%)$ & $29(100)$ & $62(100)$ & $81(99)$ & 1 \\
\hline Prolapse correction - overall, $n(\%)$ : & $26(89.5)$ & $46(74)$ & $71(87)$ & 0.08 \\
\hline Prolapse correction: artificial chordae & $23(88)$ & $38(82.6)$ & $44(62)$ & 0.007 \\
\hline Prolapse correction: P2 resection & $3(12)$ & $8(17.4)$ & $27(38)$ & 0.007 \\
\hline P1/P2 cleft closure, $n(\%)$ & $1(3.4)$ & $3(4.8)$ & $2(2.4)$ & 0.7381 \\
\hline P2/P3 cleft closure, $n(\%)$ & $1(3.4)$ & $4(6.5)$ & $6(7.3)$ & 0.7634 \\
\hline Atrial radiofrequency ablation, $n(\%)$ & $2(6.8)$ & $5(8)$ & $9(11)$ & 0.7459 \\
\hline Left atrial appendage closure, $n(\%)$ & $5(17.2)$ & $5(8)$ & $11(13.4)$ & 0.4069 \\
\hline Patent foramen ovale closure, $n(\%)$ & $2(6.8)$ & $5(8)$ & $10(12)$ & 0.6012 \\
\hline Successful repair (no/mild regurgitation), $n(\%)$ & $28(96)$ & $62(100)$ & $82(100)$ & 1 \\
\hline
\end{tabular}




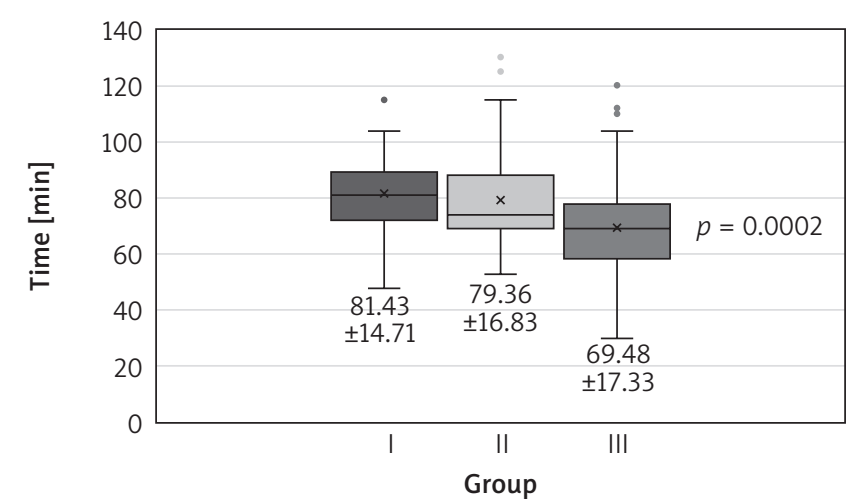

Fig. 1. Cross clamp time in groups. The data are presented as mean \pm standard deviation

Table III. Postoperative parameters in groups

\begin{tabular}{lcccc}
$\begin{array}{l}\text { Postoperative } \\
\text { parameter }\end{array}$ & $\begin{array}{c}\text { Group 1 } \\
(2012-2013) \\
(n=29)\end{array}$ & $\begin{array}{c}\text { Group 2 } \\
(2014-2015) \\
(n=62)\end{array}$ & $\begin{array}{c}\text { Group 3 } \\
(2016-2017)\end{array}$ & P-value \\
$(n=82)$ & \\
Chest revision & $5(17.2)$ & $1(1.6)$ & $1(1.2)$ & 0.0004 \\
\hline $\begin{array}{l}\text { Ventilation } \\
\text { time [min] }\end{array}$ & $\begin{array}{c}388.40 \\
\pm 334.32\end{array}$ & $\begin{array}{c}297.06 \\
\pm 139.20\end{array}$ & $\begin{array}{c}285.04 \\
\pm 130.80\end{array}$ & 0.1317 \\
\hline Transfusions & $4(13.8)$ & $5(8)$ & $5(6)$ & 0.4261 \\
\hline Pleurocentesis & $4(13.8)$ & $5(8)$ & $2(2.4)$ & 0.0770 \\
\hline $\begin{array}{l}\text { Hospitalization } \\
\text { time [days] }\end{array}$ & $7.89 \pm 2.16$ & $7.18 \pm 1.25$ & $6.73 \pm 0.98$ & 0.0005 \\
\hline
\end{tabular}

Data are shown as mean \pm standard deviation or number (percentage).

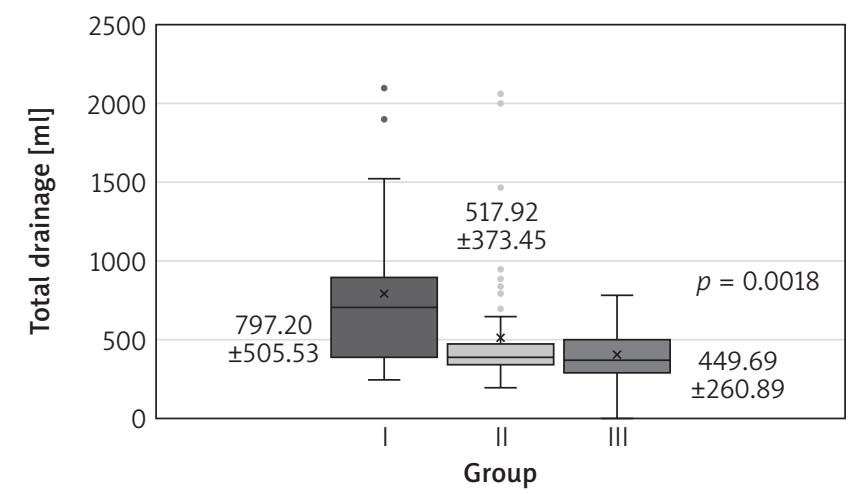

Fig. 3. Total drainage in groups. The data are presented as mean \pm standard deviation

\section{Discussion}

The global experience in mitral repair through right mini-thoracotomy has constantly improved since Carpentier, Chitwood, Mohr, and others first introduced minimally invasive mitral surgery (MIMVS) in the mid-1990s in Europe and the United States. However, many departments still intend to set up their minimally invasive mitral valve repair program. The surgery may be challenging for the surgeon and the entire team. In consequence, it is essential to guarantee constant monitoring of the results.

The first description of a learning curve was made by Wright in 1936, when he published his thesis on airplane

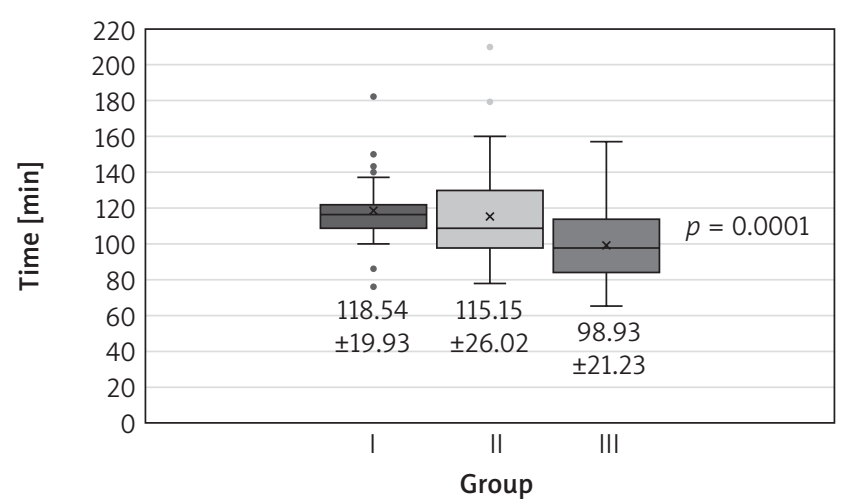

Fig. 2. Extracorporeal circulation time in groups. The data are presented as mean \pm standard deviation

component production [2]. Since then it has been used in many fields and disciplines to describe the learning process. The role of learning curve monitoring has already been appreciated in cardiac surgery. Authors of such papers usually value both organizational and operational levels [3]. The CUSUM technique allows monitoring of changes in perioperative mortality and morbidity during the patient care process. It may be repeated as often as desired, even after each operation, providing almost real-time monitoring of surgical performance [4]. Although it has been proven to be successful in examining the learning curve for offpump and minimally invasive direct coronary artery bypass (MIDCAB) [5-8], a large degree of variability in CUSUM failure curves according to individual surgeons was observed $[4,5]$. Holzhey also pointed out that the technique has not been applied in minimally invasive mitral surgery. In consequence, each institution provides analysis based on its own endpoints.

Whenever a new procedure is adapted at the institution, all the personnel must be equally involved. The Harvard Business School review of minimally invasive cardiac surgery in 16 institutions clearly identified the importance of teamwork [9]. It was also confirmed by a large minimally invasive mitral valve group analysis $[1,10]$. We conducted our first minimally invasive mitral valve repair at our institution in 2012. It was a new experience for all the personnel except the operating surgeon and the perfusionist.

The knowledge of how the procedure is being adapted in the team is essential for the program coordinator. It allows potential problems to be assessed properly. The perioperative protocol may be compared with other facilities to determine its drawbacks. Potential improvement or deterioration in surgical results affects the entire protocol.

The successful mitral valve repair was not the key aspect of this analysis, as the surgeon possesses huge experience in this kind of procedure. Each repair was immediately evaluated in transesophageal echocardiography. Whenever a correction was needed, it was performed within the same extracorporeal circulation. In consequence, all but one case received successful mitral valve repair (no regurgitation or mild regurgitation in transesophageal echocardiography) 
or valve replacement (excluded from this study, as perioperative and postoperative protocols slightly differ).

The choice of prolapse correction strategy was strictly dependent on the patient's anatomy. The risk of systolic anterior motion (SAM) was always taken into consideration. When the risk was high, quadrangular $\mathrm{P} 2$ resection was usually chosen as an alternative to artificial chordae implantation. The relatively high number of $\mathrm{P} 2$ resection strategy in group 3 is a consequence of more demanding anatomy, as more complicated regurgitation cases were qualified for minimally invasive repair when compared to previous time intervals.

The investigation to determine the primary endpoint (death, myocardial infarction, stroke, repeat surgery for mitral valve dysfunction) is important, but does not give full information about the quality of surgery and the perioperative care. Although the main points of the protocol did not change, we observed a significant reduction of the number of chest revisions and total drainage. This is probably the result of the surgeon perfecting skills and the improvement of perioperative care. The administration of blood products and pharmacological hemostatic agents was similar, but the team represented the improvement of diagnosis, reflex and confidence in real-time therapy. Shorter hospitalization is the result of improving the perioperative care, diagnosis and rehabilitation.

\section{Conclusions}

On the basis of our 6-year experience we can conclude that an experienced surgeon ensures the success of a minimally invasive mitral valve repair program. The number of chest revisions, hospitalization time and total drainage amount appear to be dependent on the experience of the operating surgeon and all the personnel involved. In general, both the personal and the institutional learning curve are flexible and cannot be defined yet. It has remained possible to improve the results through gaining of experience by the entire team. Further observation is necessary.
The procedure itself is safe and guarantees optimal results. The number of complications is low and acceptable. The long-term follow-up data regarding clinical outcome and echocardiographic evaluation are being gathered and will be published in the near future. Nevertheless, we find the perioperative analysis equally important, as it contains many factors that may directly affect the protocol, reduce the surgical risk and affect the long-term follow-up.

\section{Disclosure}

The authors report no conflict of interest.

\section{References}

1. Holzhey DM, Seeburger J, Misfeld M, Borger MA, Mohr FW. Learning minimally invasive mitral valve surgery: a cumulative sum sequential probability analysis of 3895 operations from a single high-volume center. Circulation 2013; 128: 483-491.

2. Wright TP. Factors affecting the cost of airplanes. J Aeronaut Sci 1936; 3: 122-128.

3. ElBardissi AW, Wiegmann DA, Henrickson S, Wadhera R, Sundt TM $3^{\text {rd }}$. Identifying methods to improve heart surgery: an operative approach and strategy for implementation on an organizational level. Eur J Cardiothorac Surg 2008; 34: 1027-1033.

4. Rogers CA, Reeves BC, Caputo M, Ganesh JS, Bonser RS, Angelini GD. Control chart methods for monitoring cardiac surgical performance and their interpretation. J Thorac Cardiovasc Surg 2004; 128: 811-819.

5. Holzhey DM, Jacobs S, Walther T, Mochalski M, Mohr FW, Falk V. Cumulative sum failure analysis for eight surgeons performing minimally invasive direct coronary artery bypass. J Thorac Cardiovasc Surg 2007; 134: 663-669.

6. Novick RJ, Fox SA, Stitt LW, Kiaii BB, Swinamer SA, Rayman R, Wenske TR, Boyd WD. Assessing the learning curve in off-pump coronary artery surgery via CUSUM failure analysis. Ann Thorac Surg 2002; 73: 358-362.

7. Novick RJ, Fox SA, Stitt LW, Forbes TL, Steiner S. Direct comparison of riskadjusted and non-risk-adjusted CUSUM analyses of coronary artery bypass surgery outcomes. J Thorac Cardiovasc Surg 2006; 132: 386-391.

8. Novick RJ, Fox SA, Stitt LW, Swinamer SA, Lehnhardt KR, Rayman R, Boyd WD. Cumulative sum failure analysis of a policy change from on-pump to off-pump coronary artery bypass grafting. Ann Thorac Surg 2001; 72: 10161021.

9. Edmondson A, Bohmer R, Pisano G. Speeding up team learning. Harv Bus Rev 2001; 347: 125-132.

10. Edwards J, Mazzone A, Crouch G. Minimally invasive mitral surgery: dangerous to dabble. JECT 2012; 44: 51-54. 